\title{
COMBINATION OF CENTRAL VENO-ARTERIAL CARBON DIOXIDE GAP WITH ARTERIO-VENOUS OXYGEN CONTENT DIFFERENCE DURING RESUSCITATION AS A PREDICTOR OF MULTI-ORGAN DYSFUNCTION IN SEPTIC PATIENTS
}

\author{
Amr Mohamed EL-Said, Adel Mohamed Alansary, Mohamed Abd-AlSalam \\ Al-Gendy, Hala Salah El-Din El-Ozairy*, Mohamed Hosny Abdulla**, \\ Ramy Farouk Basaly Salmoun***
}

*Department of Anesthesiology and Intensive Care and Pain Management, Faculty of Medicine - Ain Shams University

** Department Critical Care Medicine in Cairo University, *** Intensive Care Medicine, Misr University for Science and Technology

Cairo, Egypt.

Corresponding :

Ramy Farouk Basaly Mobile: 00201017139377 E mail:

Ramy_ferro@yahoo.com Received: 29/10/2019

Accepted: 26/11/201

\section{ABSTRACT:}

Background: Venous-to-arterial carbon dioxide difference ( $\mathrm{PV}$ aCO2) the PCV-aCO2/arterial-to-venous oxygen content difference (Ca-cvO2) ratio may reflect the adequacy of blood flow during shock states. We sought to test whether the development of Pv-aCO2 PcvaCO2/arterial-to-venous oxygen content difference ratio during the very early phases of resuscitation is related to multi-organ dysfunction and outcomes in a population of septic patients resuscitated targeting the usual oxygen-derived and hemodynamic parameters.

Aim of the Work: To evaluate the changes in central venous-toarterial carbon dioxide difference ( $\mathrm{Pcv}-a \mathrm{CO}_{2}$ gap) and in $\mathrm{PcV}$ $a_{C} \mathrm{O}_{2}$ /arterial-to-venous oxygen content difference $\left(\mathrm{Ca}-\mathrm{cvO}_{2}\right)$ ratio [PCv-aCO $/ 2 \mathrm{Ca}-\mathrm{CvO}_{2}$ ratio] during the early resuscitation in sepsis and septic shock as a predictor for development of multi-organ dysfunction and mortality.

Patients and Methods: This prospective observational study was performed in a 24-bed mixed ICU in a university-affiliated hospital. We examined all septic patients with a new episode admitted to the emergency room or proceeding from clinical wards during a 24-month period. After approval by Ethical Medical Committee and obtaining informed consent, simultaneous blood samples were collected from the central venous line and the arterial catheter for obtaining venous and arterial gases respectively at T0, and 6 hours (T6), 12 hours (T12) and 24 hours (T24) later. Patients were classified twice; the first one into groups (A and $B$ ) according to $\mathrm{PcvO}_{2}$ gap and the second one into groups (C and D) according to $\mathrm{PCv}-\mathrm{aCO} / \mathrm{Ca}-\mathrm{CvO}_{2}$ ratio. Group (A) Decreasing $\mathrm{PCV}$ $a_{C O}$ (high at T0, declining at T6), Group (B) Persistently high PCv$\mathrm{aCO}_{2}$ (high at T0 and T6), Group (C) Decreasing $\mathrm{PCv}-\mathrm{aCO} \mathrm{C}_{2} / \mathrm{Ca}-\mathrm{CvO}_{2}$ ratio (high at T0, declining at T6), Group (D) Persistently high PCV$\mathrm{aCO}_{2} / \mathrm{Ca}-\mathrm{CvO}_{2}$ ratio (high at $\mathrm{T0}$ and $\mathrm{T} 6$ ).

Results: During the 24-month period, 58 septic patients older than 18 years with a new episode were screened. Patients with advanced cirrhosis $(n=4)$, patients with severe chronic obstructive pulmonary disease $(n=8)$ and pregnant women $(n=4)$ were not included for analysis; additionally, two patients refused the procedure. The final sample was therefore 40 patients. Our recent study found that patients with persistently high $\mathrm{PCV}_{\mathrm{C}} \mathrm{aCO} \mathrm{C}_{2}$ gradient at T6 [8.64 \pm 1.66$]$ developed more organ dysfunction and have had a higher mortality rate (61.1\%). This study showed that the persistently elevated $\mathrm{PCv}-\mathrm{aCO} \mathrm{O}_{2} / \mathrm{Pa}-\mathrm{vO} \mathrm{O}_{2}$ ratio at time 6 was associated with a 
mortality rate of $73.7 \%$ of the patients. While decreasing of PcV$a \mathrm{CO}_{2} / \mathrm{Pa}-\mathrm{vO} \mathrm{O}_{2}$ ratio within the first 6 hours of resuscitation was associated with a survival rate of $90.5 \%$.

Conclusion: Data support the hypothesis that persistence of high $\mathrm{PCO}_{2}$ Gap and high $\mathrm{Pcv}-a \mathrm{CO}_{2} / \mathrm{Pa}-\mathrm{vO}$ ratio during the early resuscitation of patients in sepsis is associated with significant higher multi-organ dysfunction and poor outcomes in critically-ill patients.

Recommendations: Future studies on a larger number of patients are needed and should test $\mathrm{PCO}_{2}$ Gap and $\mathrm{Pcv}-a \mathrm{CO}_{2} / \mathrm{Pa}-\mathrm{vO}$ ratio as a perfusion goal during early phases of the resuscitation of patients in septic shock to confirm its reliability.

Key words: Dysoxia - Septic Shock - $\mathrm{PCO}_{2}$ gap - $\mathrm{PCV}-a \mathrm{CO}_{2} / \mathrm{Pa}-$ $\mathrm{vO}_{2}$ ratio -Organ Dysfunction - Clinical Outcome

\section{INTRODUCTION:}

Inadequate tissue perfusion is a factor in the pathogenesis and clinical course of multi-organ failure in the critically ill. Current techniques for monitoring tissue perfusion have largely focused on systemic blood flow and the balance between oxygen demand and supply. An early hemodynamic optimization that targets central venous oxygen saturation ( $\mathrm{ScvO} 2)$ and systemic hemodynamic parameters improves outcomes in severe sepsis and septic shock reinforcing the idea that tissue perfusion abnormalities are flow dependent at least during the very early stages. However, normalizing systemic hemodynamic parameters does not guarantee adequate tissue perfusion, and in fact a substantial number of patients still progress to multiorgan dysfunction and death despite meeting ScvO2 targets ${ }^{(1)}$.

Moreover, some studies demonstrate that oxygen-derived parameters such as central venous oxygen saturation $\left(\mathrm{ScvO}_{2}\right)$ are commonly normalized at ICU admission and maneuvers such as emergent intubation can quickly improve $\mathrm{ScvO}_{2}$ despite regional and tissue perfusion derangements $^{(2)}$.

In the past, authors described the coexistence of venous acidemia and increased venous carbon dioxide $\left(\mathrm{CO}_{2}\right)$ during cardiac arrest in both animals and critically ill humans. Thereafter, increases in the venous-to-arterial carbon dioxide difference $\left(\mathrm{Pcv}-\mathrm{aCO}_{2}\right)$ were reported during hypovolemic, cardiogenic, obstructive, and septic shock. Interestingly, an inverse curvilinear relationship between Pcv$\mathrm{aCO}_{2}$ and cardiac output was described, highlighting the importance of blood flow on venous $\mathrm{CO}_{2}$ accumulation. $\mathrm{Pcv}-\mathrm{aCO}_{2}$ thus aroused clinical interest as a marker of global perfusion during shock states ${ }^{(3)}$.

Other data suggest that high Pcv$\mathrm{aCO}_{2}$ could identify septic patients who remain inadequately resuscitated despite achieving oxygen metabolism targets, reinforcing the notion of $\mathrm{Pcv}_{-} \mathrm{aCO}_{2}$ as a marker of global perfusion due to its ability to track blood flow alterations or even detect anaerobic $\mathrm{CO}_{2}$ generation ${ }^{(4)}$.

Furthermore, patterns of recovery or derangement of $\mathrm{Pcv}-\mathrm{aCO}_{2}$ during very early stages of resuscitation of septic shock have not been widely described and recent studies trying to demonstrate the reliability of Pcv$\mathrm{aCO}_{2}$ as a tool in resuscitation of septic patients could have been influenced by selection bias because not all potential patients were elected to catheter insertion and goal-directed therapy ${ }^{(5)}$.

In addition, some authors have suggested that correcting the $\mathrm{Pcv}-\mathrm{aCO}_{2}$ gap by an approximation of the oxygen consumption, the $\mathrm{Pcv}-\mathrm{aCO}_{2} /$ arterial-to-venous 
oxygen content difference $\left(\mathrm{Ca}-\mathrm{CvO}_{2}\right)$ ratio, might be superior to the $\mathrm{Pcv}-\mathrm{aCO}_{2}$ gap to detect anaerobic metabolism, and there-fore should be a more reliable parameter to guide the resuscitation process ${ }^{(6)}$.

\section{PATIENTS AND METHODS:}

This prospective observational study was performed in a 24-bed mixed ICU in a university-affiliated hospital. We examined all septic patients with a new episode admitted to the emergency room or proceeding from clinical wards during a 24month period. Patients were excluded if they were younger than 18 years old, pregnant, had severe chronic obstructive pulmonary disease, advanced liver cirrhosis (ChildPugh C), chronic renal failure on regular dialysis, Patients with $\mathrm{Pcv}-\mathrm{aCO} 2$ gap less than $6 \mathrm{mmHg}$, Patients with Pcv-aCO2/Ca$\mathrm{cvO} 2$ ratio less than 1.4 and Patients already enrolled in another study

\section{General management:}

All patients were evaluated by the Intensive Care Unit rapid response team according to our local procedures. Each patient was equipped with an arterial cannula and a central venous catheter. Our early goal-directed therapy included a bundle of interventions that sought to obtain: mean arterial pressure $\geq 65 \mathrm{mmHg}$; urine output $\geq 0.5 \mathrm{ml} / \mathrm{kg} /$ minute; normalization of serum lactate; and ScvO2 $\geq 70 \%$ The use of vasopressors was standardized to maintain a mean arterial pressure $\geq 65 \mathrm{mmHg}$, and repeated fluid challenges with crystalloids or colloids were used to optimize the stroke volume as well as to allow the lowest dose of vasopressors. Dobutamine was added for persistent $\mathrm{ScvO} 2 \leq 70 \%$ after fluid resuscitation if hematoctrit was less than $30 \%$. A low dose of $50 \mathrm{mg}$ of hydro-cortisone was given within 6 hours of resuscitation when use of vasopressors persisted after an adequate fluid restitution. Mechanical ventilation was provided when needed under light sedation (midazolam) and analgesia (fentanyl); the tidal volume was limited to 6 to $8 \mathrm{ml} / \mathrm{kg}$. Finally, stress ulcer and venous thrombosis prophylaxis were provided according to international recommendations.

\section{Study protocol:}

This study was done after approval by Ethical Medical Committee and obtaining informed consent. A written informed consent was waived because no new therapeutic interventions were performed and all measurements and procedures routinely followed the local protocols for the management of septic patients. Simultaneous blood samples were collected from the central venous line and the arterial catheter for obtaining venous and arterial gases respectively and also lactate measurements at T0, and 6 hours (T6), 12 hours (T12) and 24 hours (T24) later. Measured variables included arterial oxygen tension $\left(\mathrm{PaO}_{2}\right)$, arterial carbon dioxide tension $\left(\mathrm{PaCO}_{2}\right)$, central venous oxygen tension $\left(\mathrm{PcvO}_{2}\right)$, central venous carbon dioxide tension $\left(\mathrm{PcvCO}_{2}\right)$, arterial oxygen saturation $\left(\mathrm{SaO}_{2}\right)$ and central venous oxygen saturation $\left(\mathrm{ScvO}_{2}\right)$. Furthermore, SOFA Score was measured daily.

Pcv-aCO $\mathrm{C}_{2}$ was defined as the difference between the central venous $\mathrm{CO}_{2}$ partial pressure and the arterial $\mathrm{CO}_{2}$ partial pressure. The arterial oxygen content $\left(\mathrm{CaO}_{2}\right)$, central venous oxygen content $\left(\mathrm{CcvO}_{2}\right)$, arterial-venous oxygen content difference $\left(\mathrm{Ca}-\mathrm{cvO}_{2}\right)$, and $\mathrm{Pcv}-\mathrm{aCO}_{2} / \mathrm{Ca}-\mathrm{cvO}_{2}$ ratio were calculated according to the following formulas: ${ }^{(7)}$

$$
\begin{array}{ll}
\mathrm{CaO}_{2}= & \left(1.34 \times \mathrm{SaO}_{2} \times \mathrm{Hb}\right)+\left(0.003 \times \mathrm{PaO}_{2}\right) \\
\mathrm{CcvO}_{2}= & \left(1.34 \times \mathrm{ScvO}_{2} \times \mathrm{Hb}\right)+\left(0.003 \times \mathrm{PcvO}_{2}\right) \\
\mathrm{Ca}-\mathrm{cvO}_{2}= & \mathrm{CaO}_{2}-\mathrm{CcvO}_{2} \\
\mathrm{Pcv}-\mathrm{aCO}_{2} \text { gap }= & \mathrm{PcvCO}_{2}-\mathrm{PaCO}_{2} \\
{\mathrm{Pcv}-\mathrm{aCO}_{2} / \mathrm{Ca}-\mathrm{cvO}_{2} \text { ratio }=} & {\mathrm{Pcv}-\mathrm{aCO}_{2} / \mathrm{Ca}-\mathrm{cvO}_{2}}
\end{array}
$$


Patients were classified twice; the first one into groups (A and $\mathrm{B}$ ) according to $\mathrm{PcvO}_{2}$ gap and the second one into groups $\left(\mathrm{C}\right.$ and $\mathrm{D}$ ) according to $\mathrm{Pcv}-\mathrm{aCO}_{2} / \mathrm{Ca}-\mathrm{cvO}_{2}$ ratio. Group (A) Decreasing $\mathrm{Pcv}-\mathrm{aCO}_{2}$ (high at T0, declining at T6), Group (B) Persistently high $\mathrm{Pcv}_{-} \mathrm{aCO}_{2}$ (high at $\mathrm{T} 0$ and T6), Group (C) Decreasing Pcv-aCO $\mathrm{CO}_{2} / \mathrm{Ca}-$ $\mathrm{cvO}_{2}$ ratio (high at $\mathrm{T} 0$, declining at $\mathrm{T} 6$ ), Group (D) Persistently high $\mathrm{Pcv}-\mathrm{aCO}_{2} / \mathrm{Ca}$ $\mathrm{cvO}_{2}$ ratio (high at $\mathrm{T} 0$ and $\mathrm{T} 6$ )

\section{Data analysis:}

Data were collected, revised, coded and entered to the Statistical Package for Social Science (IBM SPSS) version 23. The quantitative data were presented as mean, standard deviations and ranges when parametric and median with inter-quartile range (IQR) when non parametric and percentiles were used to assess the distribution of some parameters. Also, qualitative variables were presented as number and percentages.

The comparison between groups regarding qualitative data was done by using Chi-square test and/or Fisher exact test when the expected count in any cell found less than 5.The comparison between two independent groups with quantitative data and parametric distribution was done by using Independent t-test while with nonparametric distribution was done by using Mann-Whitney test. Also, receiver operating characteristic curve (ROC) was used to assess predictors of mortality at 28 day with its sensitivity, specificity, positive predictive value (PPV), negative predictive value (NPV) and area under curve (AUC). The confidence interval was set to $95 \%$ and the margin of error accepted was set to $5 \%$. So, the $p$-value was considered significant as the following: P-value $>0.05$ : Non significant (NS), P-value < 0.05: Significant (S), Pvalue $<0.01$ : Highly significant (HS)

\section{RESULTS:}

During the 24-month period, 58 septic patients older than 18 years with a new episode were screened. Patients with advanced cirrhosis $(n=4)$, patients with severe chronic obstructive pulmonary disease $(n=8)$ and pregnant women $(n=4)$ were not included for analysis; additionally, two patients refused the procedure. The final sample was therefore 40 patients.

Patients' characteristics of group A and B showed no statistically significant difference between the two groups regarding gender and age (Table 1).

Table (1): Patient's characteristics of groups A and B:

\begin{tabular}{|c|c|c|c|c|c|}
\hline \multicolumn{2}{|c|}{} & Group A & Group B & P-value & Sig. \\
\cline { 3 - 4 } \multirow{2}{*}{ Gender } & No. $=22$ & No. $=18$ & & \\
\cline { 2 - 5 } & Females (Number and \%) & $13(59.1 \%)$ & $13(72.2 \%)$ & \multirow{2}{*}{$0.386^{*}$} & NS \\
\hline Age (years) & Males (Number and \%) & $9(40.9 \%)$ & $5(27.8 \%)$ & & \\
\hline
\end{tabular}

The need of inotropes was $16(72.7 \%)$ Vs. $16(88.9 \%)$ in groups $\mathrm{A}$ and $\mathrm{B}$ respectively and mechanical ventilation was $8(36.4 \%)$ Vs. $12(66.7 \%)$ in groups $\mathrm{A}$ and
B respectively. There no statistically significant difference between groups (A \& B) regarding need of inotropes and mechanical ventilation (Diagram 1). 


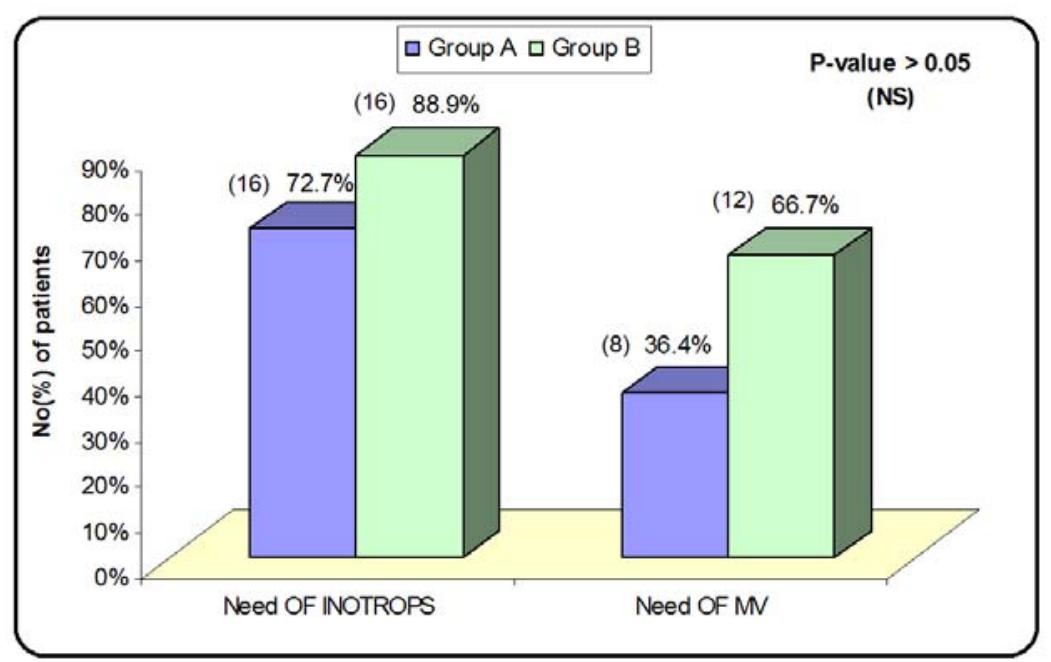

Diagram (1): Need of Inotropes and Mechanical ventilation in groups A and B.

The number of organs dysfunction was significantly lower in group A $(2.20 \pm 1.57)$ compared to group B $(3.93 \pm 1.77)$ (Table 2). The total length of stay was comparable between the two groups $(7.55 \pm 4.52)$ in group A and (8.33 \pm 5.03$)$ in group B (Table 2). However, mortality was significantly higher in group B 11(61.1\%) compared to Table (2): Number of Organ dysfunction, length of total stay and mortality in groups A and B:

\begin{tabular}{|c|c|c|c|c|c|}
\hline \multicolumn{2}{|l|}{} & Group A & Group B & P-value & Sig. \\
\cline { 3 - 4 } & No. $=22$ & No. $=18$ & & \\
\hline Number of organs dysfunction & Mean \pm SD & $2.20 \pm 1.57$ & $3.93 \pm 1.77$ & $0.010 \bullet$ & S \\
\hline $\begin{array}{c}\text { Length of total stay (days) } \\
\text { (Intensive care unit and hospital stay) }\end{array}$ & Mean \pm SD & $7.55 \pm 4.52$ & $8.33 \pm 5.03$ & $0.605 \bullet$ & NS \\
\hline \multicolumn{2}{|c|}{ Mortality at 28 day (Number and \%) } & $5(22.7 \%)$ & $11(61.1 \%)$ & $0.014^{*}$ & S \\
\hline
\end{tabular}

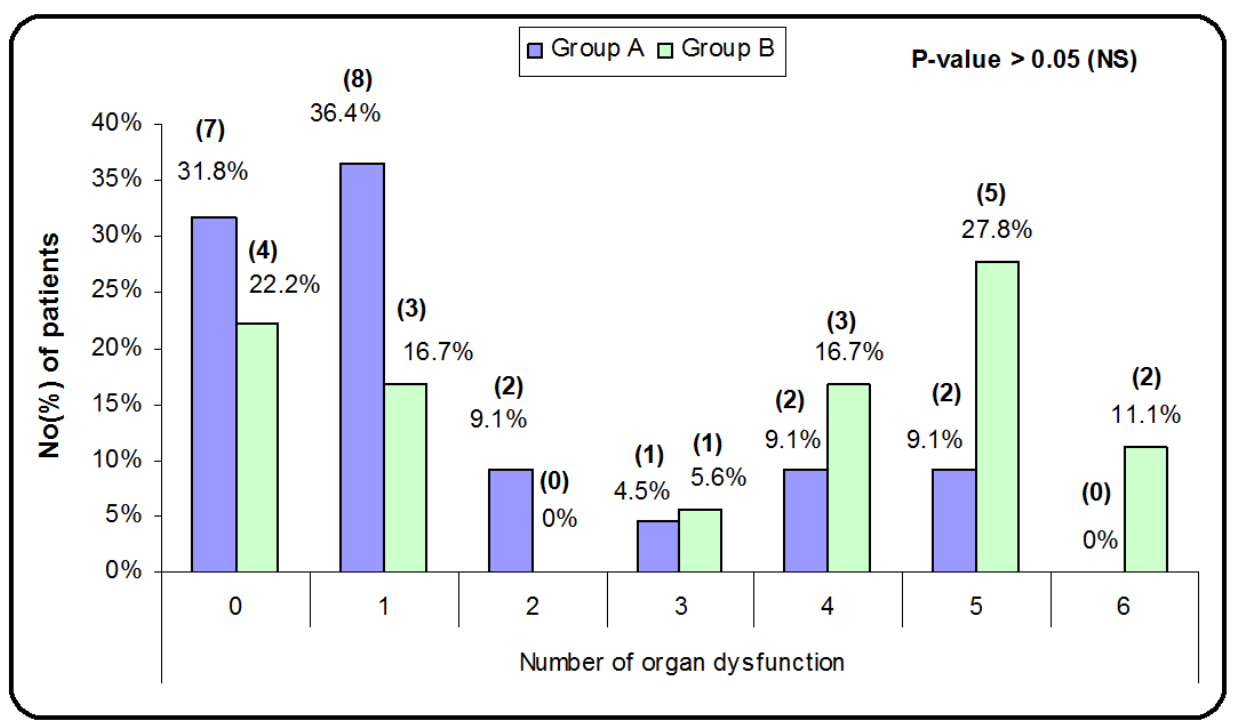

Diagram (2): Number of Organ dysfunction in groups A and B. group A 6(22.7\%) (Table 2). Number of organs dysfunction was compared between groups A and B Diagram 2) with more patients in group A suffering from one organ dysfunction $8(36.4 \%)$ while more patients in group B suffered 5 organ dysfunctions 5 $(27.8 \%)$. 
SOFA Score in groups A and B showed statistically significance difference on the $3^{\text {rd }}$ day being significantly lower in group A $\{4.5(3-7)\}$ than in group B $\{8(3-12)\}$ (Diagram 3)

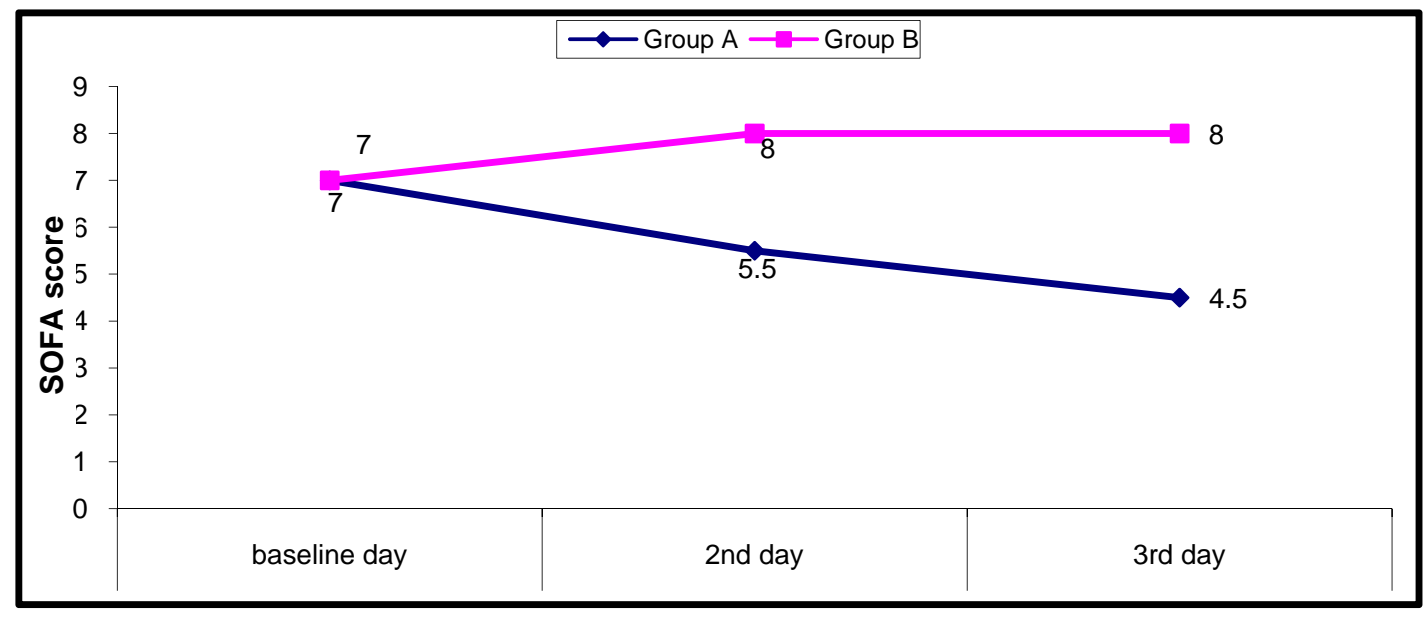

Diagram (3): SOFA Score distribution in groups A and B.

Also, for the two groups $\mathrm{C}$ and $\mathrm{D}$, there was no statistically significant difference between the two groups regarding gender and age (Table 3). Group C and D showed comparable results in the need of inotropes. it was $15(71.4 \%)$ Vs. $17(89.5 \%)$ in groups $\mathrm{C}$ and $\mathrm{D}$ respectively. However, the need of mechanical ventilation was significantly higher in group D 14(73.3\%) compared to group C 6(28.6\%) (Diagram4).

Table (3): Patients characteristics in group C and D:

\begin{tabular}{|c|c|c|c|c|c|}
\hline \multicolumn{2}{|c|}{} & Group C & Group D & \multirow{2}{*}{ P-value } & Sig. \\
\cline { 3 - 4 } \multirow{2}{*}{ Gender } & Females (Number and \%) & No. $=21$ & No. $=19$ & & \\
\cline { 2 - 4 } & Males (Number and \%) & $8(38.9 \%)$ & $13(68.4 \%)$ & 0.666 & NS \\
\hline Age (years) & Mean \pm SD & $64.00 \pm 11.27$ & $6(31.6 \%)$ & & \\
\hline
\end{tabular}

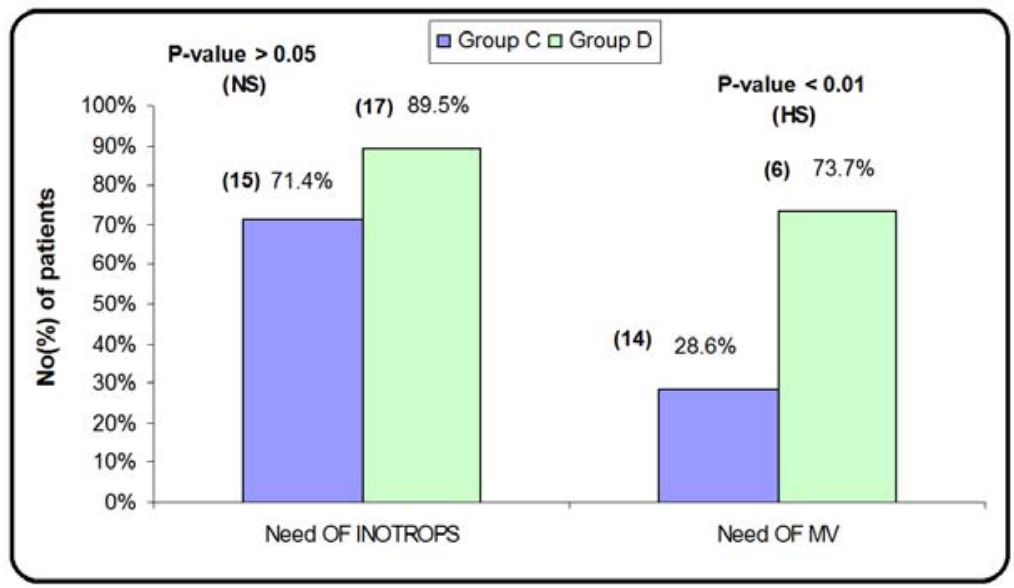

Diagram (4): Need of inotropes and need of mechanical ventilation in group C and D.

The number of organs dysfunction was significantly lower in group C (1.62 \pm 1.19$)$ compared to group D $(4.19 \pm 1.47)$, also the mortality was significantly lower $2(9.5 \%)$ in group C versus $14(73.3 \%)$ in group D (Table
3). More patients in group $\mathrm{C}$ suffered from one organ dysfunction $9(42.9 \%)$ while more patients in group D suffered from 5 organ dysfunction 6(31.6\%) (Diagram 5). 
Combination of central veno-arterial carbon dioxide gap with arterio-venous oxygen content ...

Table (4): Number of Organs dysfunction, length of total stay and mortality in group C and D:

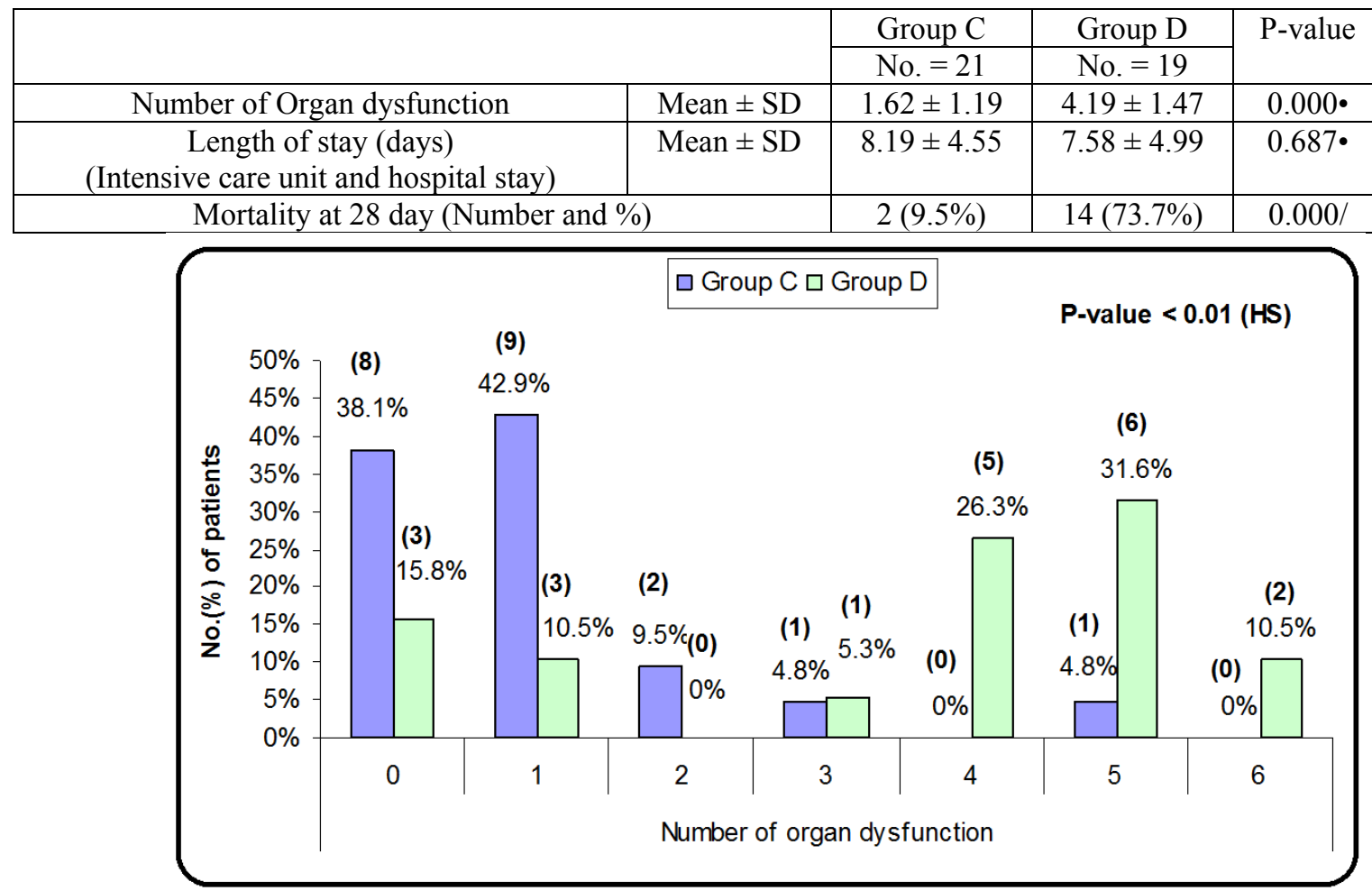

Diagram (5): Distribution of organ dysfunction in group C and D.

SOFA Score in group C and D showed statistically significance difference on the $3^{\text {rd }}$ day being significantly lower in group $\mathrm{C}\{4(3-7)\}$ than in group D $\{10(3-12)\}$ (Diagram 6).

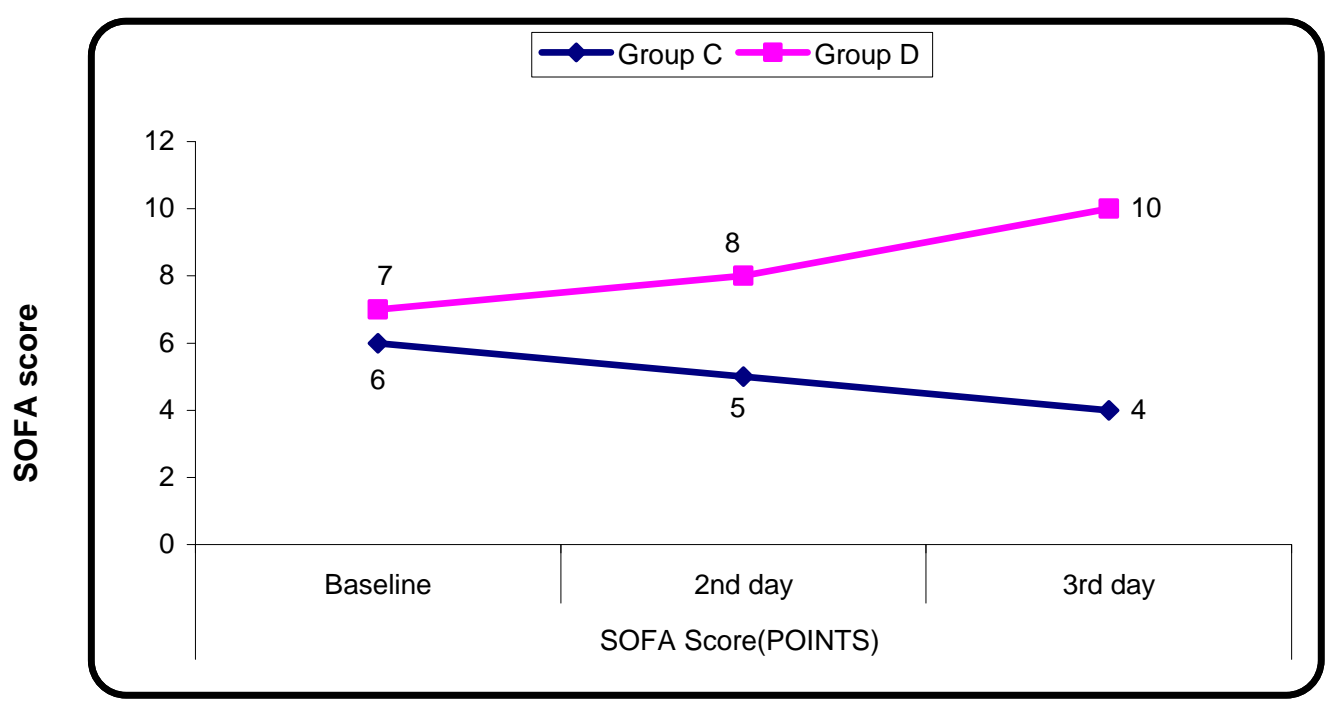

Diagram (6): SOFA Score in group C and D.

Pcv-aCO 2 Gap had diagnostic performance in prediction of death, with sensitivity $100 \%, 87.5 \%, 76.9 \%$ at T6, T12, T24 respectively and specificity $50 \%, 75 \%, 82.4 \%$ at T6, T12, T24 respectively (Table 5 and Diagram 7). 


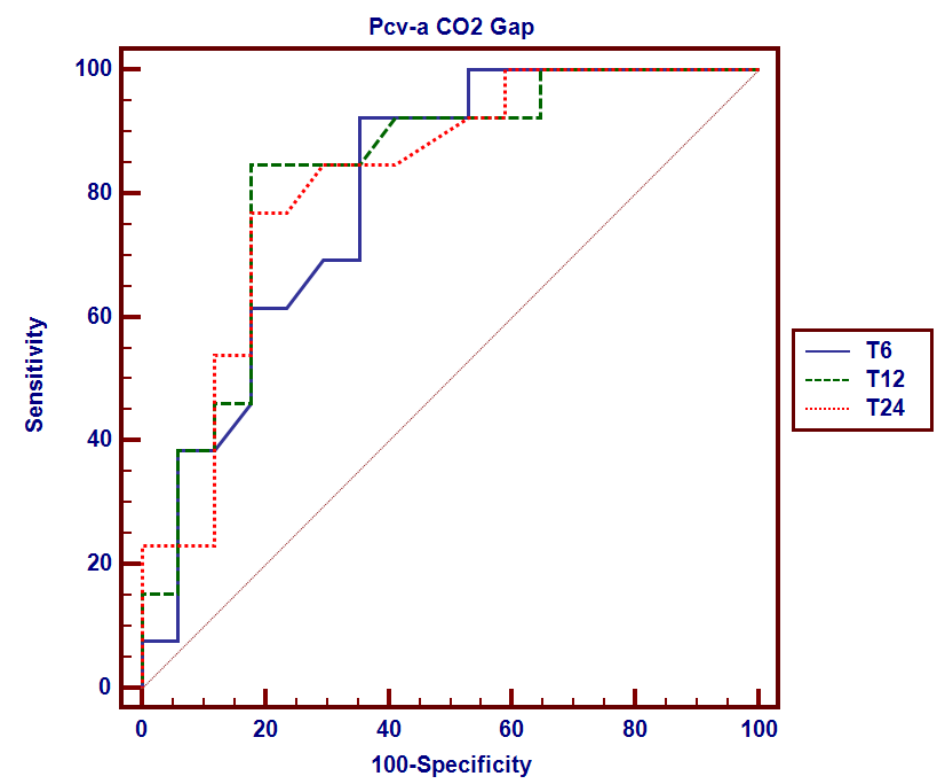

Diagram (7): Receiver operating characteristic curve (ROC) for Pcv-a $\mathrm{CO}_{2}$ Gap at T6 and T12 as predictors for mortality

Table (5): Receiver operating characteristic curve (ROC) for Pcv-a $\mathrm{CO}_{2}$ Gap at T6 and $\mathrm{T} 12$ as predictors for mortality

\begin{tabular}{|c|c|c|c|c|c|c|}
\hline & Cut off point & AUC & Sensitivity & Specificity & PPV & NPV \\
\hline T6 & $>6$ & 0.773 & 100 & 50 & 57.1 & 100 \\
\hline T12 & $>6.4$ & 0.852 & 87.5 & 75 & 70 & 90 \\
\hline T24 & $>5.9$ & 0.821 & 76.9 & 82.4 & 76.9 & 82.4 \\
\hline
\end{tabular}

Pcv-aCO $/ \mathbf{C a}_{2} \mathbf{C v O} \mathrm{O}_{2}$ ratio had perfect diagnostic performance in prediction of death, with sensitivity $81.25 \%, 100 \%, 93.75 \%$ at T6, T12, T24 respectively and specificity $83.33 \%, 66.67 \%$, $37.5 \%$ at $\mathrm{T} 6, \mathrm{~T} 12$, and $\mathrm{T} 24$ respectively(Table 6 and Diagram 8).

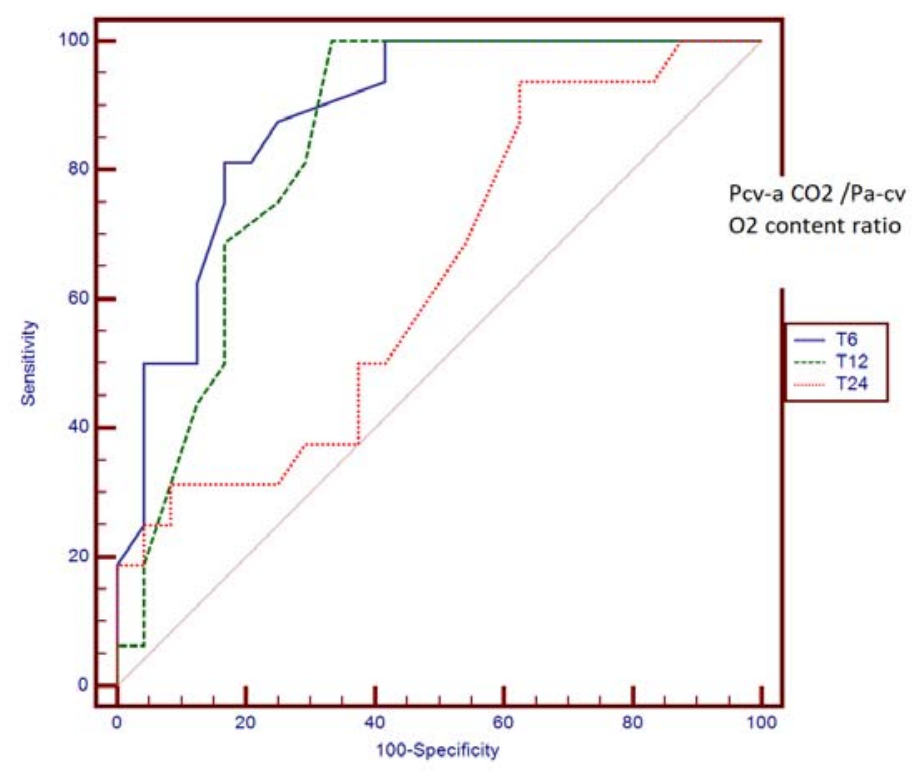

Diagram (8): Receiver operating characteristic curve (ROC) for $\mathrm{Pcv}-\mathrm{aCO}_{2} / \mathrm{Ca}-\mathrm{cvO}_{2}$ ratio at $\mathrm{T} 6, \mathrm{~T} 12$ and $\mathrm{T} 24$ as predictors for mortality. 
Table (6): Receiver operating characteristic curve (ROC) for Ratio at T6 and T12 and T24 as predictors for mortality

\begin{tabular}{|c|c|c|c|c|c|c|}
\hline & Cut off point & AUC & Sensitivity & Specificity & PPV & NPV \\
\hline T6 & $>1.9$ & 0.883 & 81.25 & 83.33 & 76.5 & 87.0 \\
\hline T12 & $>1.6$ & 0.845 & 100.00 & 66.67 & 66.7 & 100.0 \\
\hline T24 & $>1.3$ & 0.637 & 93.75 & 37.50 & 50.0 & 90.0 \\
\hline
\end{tabular}

\section{DISCUSSION:}

We studied a cohort of patients during the very early phases of septic shock who were subjected to a comprehensive resuscitation aimed to target the usual hemodynamic and oxygen metabolism parameters. Our study found that patients with persistently high $\mathrm{Pcv}-\mathrm{aCO}_{2}$ gradient at T6 [8.64 \pm 1.66$]$ developed more organ dysfunction and have had a higher mortality rate $(61.1 \%)$.

In concordance with our study, Ospina and his colleagues studied 108 patients with septic shock, they measured $\mathrm{Pcv}-\mathrm{aCO}_{2}$ gradient at time 0 and after 6 hours, they found that those with persistently high Pcv$\mathrm{aCO}_{2}$ gradient at $\mathrm{T} 6$ [7.0 (5.8 to 9.7)] developed more organ dysfunction assessed by SOFA score at day-3 ( $\mathrm{P}<0.001)$, than patients evolving with normal $\mathrm{Pcv}-\mathrm{aCO}_{2}$ gradient during the first 6 hours of resuscitation [4.4 (2.7-5.4]. Additionally, they observed that persistently high Pcv$\mathrm{aCO}_{2}$ gradient were associated with a lower survival at day-28 ${ }^{(9)}$.

Similar to our results, Van Beest and his colleagues recruited 60 patients with septic shock. They measured Pcv-aCO $\mathrm{CO}_{2}$ gradient at time 0 and after 6 hours. They found a higher $\mathrm{Pcv}-\mathrm{aCO}_{2}$ gradient at Time $0(6.5 \pm 3.0$ vs. $3 \pm 1.8, \mathrm{P}<0.001)$ and Time $6(8 \pm 4$ vs. $3 \pm 2, \quad \mathrm{P}<0.001)$ in non survivors vs. survivors respectively ${ }^{(5)}$.

On the other hand, a study done by Machado and his colleagues on 43 patients with severe sepsis and septic shock found that SOFA Time 0, and SOFA Time 24 hour scores were $7.9 \pm 3.8$, and $8.0 \pm 4.3$, respectively. $\triangle \mathrm{CO} 2$ at $\mathrm{T} 0(\mathrm{P}=0.60)$ and its trend $(\mathrm{P}=0.36)$ are not related to $\triangle$ SOFA. The analysis of $\mathrm{SvcO} 2$ also showed no significant finding. So $\triangle \mathrm{PCO} 2$ and $\mathrm{SvcO} 2$ and its increasing trends in first 24 hours are unrelated to the SOFA score which was insignificant with mortality, which may be related to lower number of patients included in the study ${ }^{(8)}$.

\section{Regarding Pcv-aCO2/ Pa-vO2 ratio:}

Our study showed that the persistently elevated $\mathrm{Pcv}-\mathrm{aCO} \mathrm{CO}_{2} / \mathrm{Pa}-\mathrm{vO}_{2}$ ratio at time 6 was associated with a mortality rate of $73.7 \%$ of the patients. While decreasing of $\mathrm{Pcv}-\mathrm{aCO}_{2} / \mathrm{Pa}-\mathrm{vO}_{2}$ ratio within the first 6 hours of resuscitation was associated with a survival rate of $90.5 \%$.

Monnet and his colleagues found that ratio of the central venous-to-arterial $\mathrm{CO}_{2}$ tension difference $\left(\triangle \mathrm{PCO}_{2}\right)$ over the arterialto-venous oxygen content difference $\left(\Delta \mathrm{ContO}_{2}\right)$, predicted an increase in $\mathrm{VO}_{2}$ after a fluid-induced increase in $\mathrm{DO}_{2}$ and thus, can be able to detect the presence of global tissue hypoxia ${ }^{(\mathbf{1 0})}$.

Our study supports the notion that serial measurements of the $\mathrm{Pcv}-\mathrm{aCO}_{2} / \mathrm{Pa}-\mathrm{vO}_{2}$ ratio during resuscitation may serve as surrogate markers of the payment of the oxygen debt.

It was also observed in our study that $\mathrm{Pcv}-\mathrm{aCO}_{2} / \mathrm{Pa}-\mathrm{vO}_{2}$ ratio is superior to Pcv$\mathrm{aCO}_{2}$ in detecting organ dysfunction and mortality.

In concordance with our study Huai-wu and his colleagues found that The Pcv-aCO gap and $\mathrm{Pcv}-\mathrm{aCO}_{2} / \quad \mathrm{Pa}-\mathrm{vO}_{2}$ ratio were significantly and negatively related to the lactate clearance ${ }^{(11)}$. 
Mallat and his colleagues studied eighty patients with septic shock and found that decreasing Lactate level alone was an independent predictor of 28-day mortality. Also, they found that Monitoring PCO2 may be a useful tool to assess the adequacy of tissue perfusion during resuscitation in combination with lactate level ${ }^{(\mathbf{1 2})}$.

\section{conclusion and recommendations}

Data support the hypothesis that persistence of high $\mathrm{PCO}_{2}$ Gap and high Pcv$\mathrm{aCO}_{2} / \mathrm{Pa}-\mathrm{vO}_{2}$ ratio during the early resuscitation of patients in sepsis is associated with significant higher multiorgan dysfunction and poor outcomes in critically-ill patients.

\section{REFERENCES:}

1. Rivers E, Nguyen B, Havstad S, et al. Early goal-directed therapy in the treatment of severe sepsis and septic shock. N Eng J Med 2001; 345: 1368-1377.

2. Hernandez G, Pena H, Cornejo R, et al. Impact of emergency intubation on central venous oxygen saturation in critically ill patients: a multicenter observational study. Crit Care Med 2009; 13:R63.

3. Ospina-Tascón GA, Bautista-Rincón DF, Umaña $M$, et al. Persistently high venousto-arterial carbon dioxide differences during early resuscitation are associated with poor outcomes in septic shock. Critical Care. 2013; 17(6):R294.

4. Vallee F, Vallet B, Mathe O, et al. Central venous-to-arterial carbon dioxide difference: an additional target for goaldirected therapy in septic shock? Intensive Care Med 2008; 34: 2218-2225.

5. van Beest PA, Lont MC, Holman ND, et al. Central venous-arterial pCO2 difference as a tool in resuscitation of septic patients. Intensive Care Medicine. 2013; 39(6):10349.
6. Mekontso-Dessap A, Castelain V, Anguel $\mathrm{N}$, et al. Combination of venoarterial PCO2 difference with arteriovenous $\mathrm{O} 2$ content difference to detect anaerobic metabolism in patients. Intensive Care Med 2002; 28 : 272-7.

7. Mesquida J, Saludes P, Gruartmoner G et al. Central venous-to-arterial carbon dioxide difference combined with arterial-to-venous oxygen content difference is associated with lactate evolution in the hemodynamic resuscitation process in early septic shock. Critical Care 2015; 19: 126-132.

8. Machado F, Guarnieri A, Freitas FG, et al. Prognostic value of central venous-arterial $\mathrm{PCO}_{2}$ difference in severe sepsis and septic shock patients. Critical Care. 2010; 14(1):P155.

9. Ospina-Tascón GA, Umaña M, Bermúdez $\mathrm{W}$, et al. Combination of arterial lactate levels and venous-arterial $\mathrm{CO} 2$ to arterialvenous $\mathrm{O} 2$ content difference ratio as markers of resuscitation in patients with septic shock. Intensive Care Medicine. 2015; 41(5):796-805.

10. Monnet X, Julien F, Ait-Hamou N, et al. Lactate and venoarterial carbon dioxide difference/arterial-venous oxygen difference ratio, but not central venous oxygen saturation, predict increase in oxygen consumption in fluid responders, Crit Care Med 2013; 41:1412-20.

11. Huai-wu H, Liu DW, Long Y, et al. High central venous-to-arterial $\mathrm{CO} 2$

difference/arterial-central venous $\mathrm{O} 2$ difference ratio is associated with poor lactate clearance in septic patients after resuscitation. Journal of Critical Care. 2016; 31(1):76-81.

12. Mallat J, Lemyze M, Tronchon L, et al. Use of venous-to-arterial carbon dioxide tension difference to guide resuscitation therapy in septic shock. World Journal of Critical Care Medicine. 2016; 5(1):47. 
إستخدام الفارق بين ضغط ثاني اكسيد الكربون الوريدي المركزي الشرياني والفارق بين محتوي

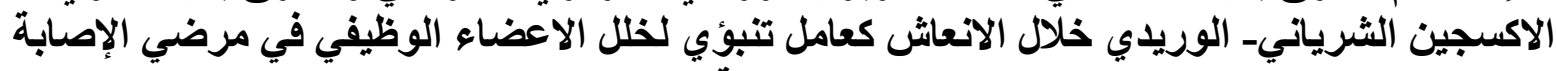
التسممية

عمرو محمد السعيد، عادل محمد الأنصاري، محمد عبد السلام الجندي، هالة صلاح الدين العزيري٪،

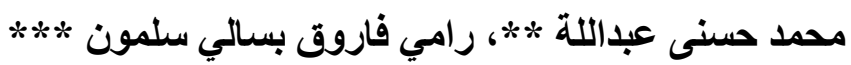

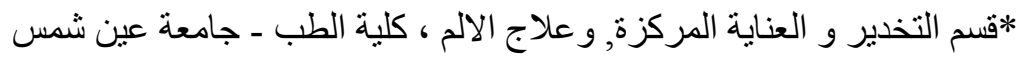

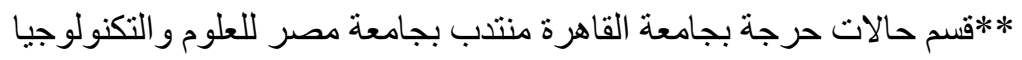

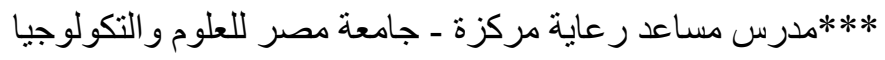

مقدمة: يعتبر زيادة فرق ضغط الدم الوريدي- الثرياني لثاني اكسيد الكربون علامة قيمة علي نقص أكسجة الانسجة في

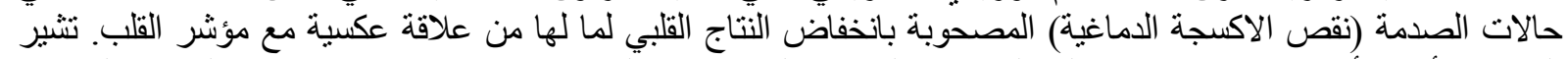

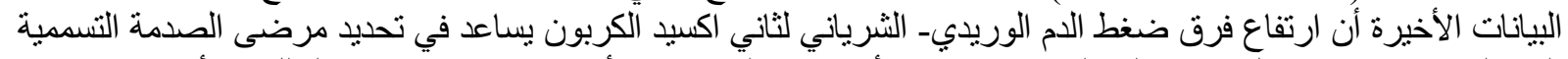

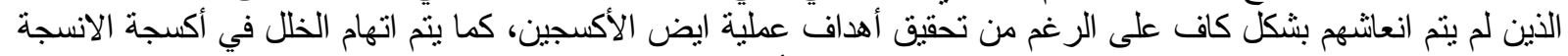

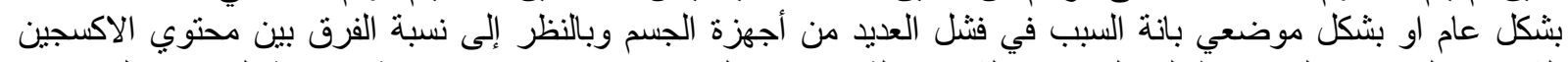

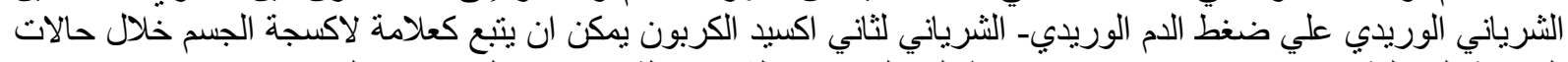

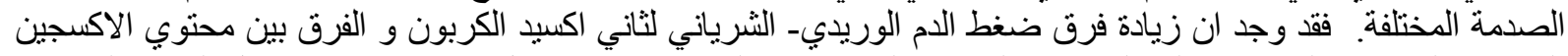

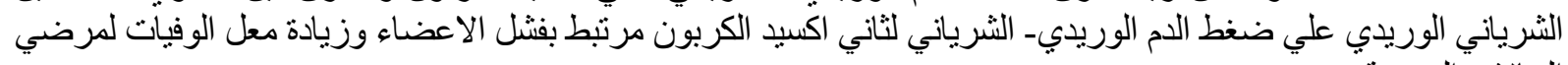
الحالات "الحرجة.

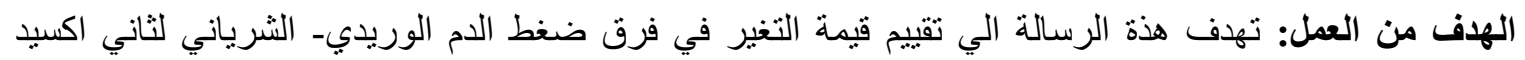

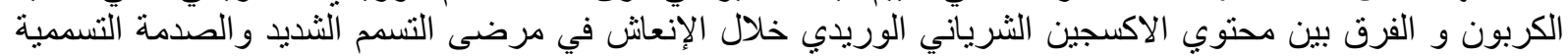
باعنباره مؤشر ا لحدوث الختلال وظيفي للأعضاء وايضا معدل الوكين الوفيات.

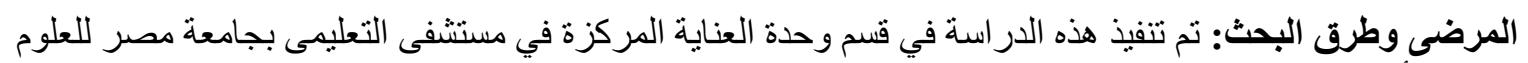

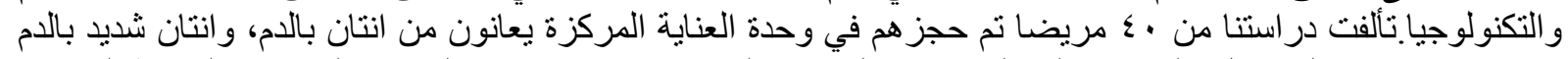

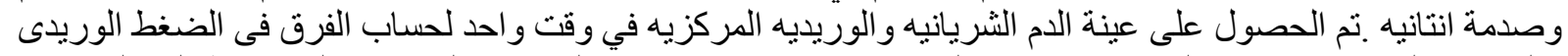

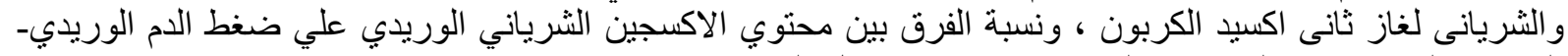

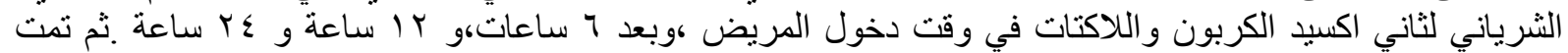

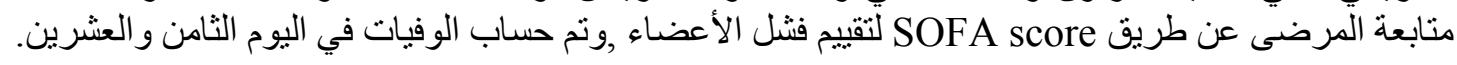

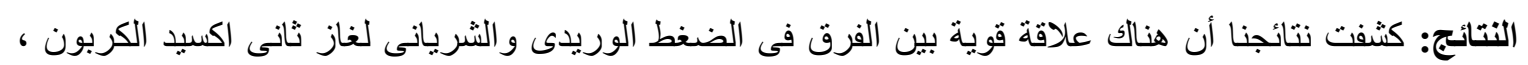

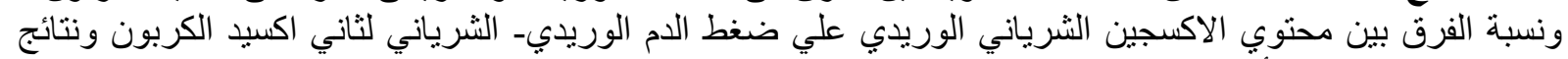

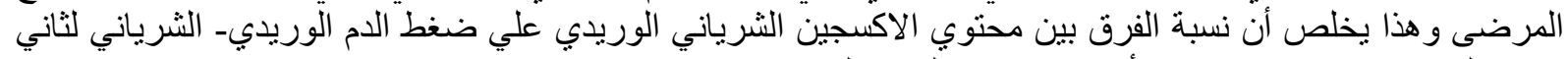

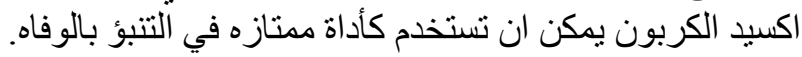

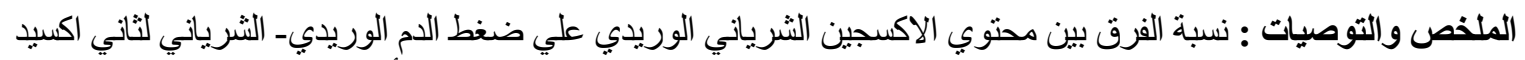

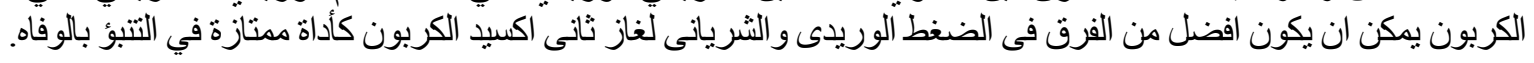

